\title{
Evaluation of Groundwater Suitability for Domestic and Irrigational Purposes: A Case Study from Mingoa River Basin, Yaounde, Cameroon
}

\author{
Tabue Youmbi Jean Ghislain ${ }^{1}$, Feumba Roger ${ }^{1}$, Wethe Joseph ${ }^{2}$, \\ Ekodeck Georges Emmanuel ${ }^{1}$, De Marsily Ghislain ${ }^{3}$ \\ ${ }^{1}$ Department of Earth Sciences, University of Yaounde I, Yaounde, Cameroon \\ ${ }^{2}$ Centre Régional pour l'Eau Potable et l'Assainissement à Moindre coût, Ouagadougou, Burkina Faso \\ ${ }^{3}$ Université Pierre Marie Curie de Paris 6 et Ecole des Mines de Paris, Paris, France \\ Email: tabueley@yahoo.fr
}

Received February 23, 2012; revised March 21, 2012; accepted April 22, 2012

\begin{abstract}
A baseline study involving analyses of subsurface water samples from the Mingoa river basin (longitude: $11^{\circ} 30^{\prime} \mathrm{E}$; latitude: $3^{\circ} 52^{\prime} \mathrm{N}$ ) in migmatitic complex in Yaounde Cameroon (central Africa) was carried out to assess their suitability for drinking, domestic and agricultural purposes. Study results show that $\mathrm{pH}$ is ranged between $5.1 \leq \mathrm{pH} \leq 5.8$ and then, induces acidic waters. Groundwater samples are generally characterized by low conductivity values, of which $100 \%$ are within the range $(55 \leq \mathrm{EC} \leq 1500 \mu \mathrm{S} / \mathrm{cm})$. The mean values of the major cations $\left(\mathrm{Ca}^{2+}, \mathrm{Mg}^{2+}, \mathrm{Na}^{+}, \mathrm{K}^{+}\right)$and anions $\left(\mathrm{SO}_{4}^{2-}, \mathrm{Cl}^{-}, \mathrm{HCO}_{3}^{-}\right)$are all within the World Health Organization (WHO) standards. Two of the springs sampled have nitrate $\left(\mathrm{NO}_{3}^{-}\right)$contamination. Even though $\mathrm{NO}_{3}^{-}$contamination and acidic waters exist in some of the springs, the majority of the springs are excellent for agricultural and domestic purposes. Assessment of the groundwater for agricultural irrigation revealed two main categories. These are low salinity-low sodicity (C1-S1) and medium salinity-low sodicity (C2-S1), using the US Salinity Laboratory (USSL) classification scheme. As much as all of the samples plotted in the "excellent to good" and "good to permissible" categories on the Wilcox diagram. The groundwater in the study area may therefore be regarded as good for irrigation activities. The major identifiable geochemical processes responsible for the evolution of the various ions are mineral weathering, chemical reactions and anthropogenic activities.
\end{abstract}

Keywords: Groundwater; Suitability; Mingoa Watershed; Yaounde; Cameroon; Central Africa

\section{Introduction}

Groundwater is a valuable natural resource; it occurs almost in all geological formations beneath the earth surface not in a single widespread aquifer but in thousands of local aquifer systems with similar characteristics [1]. The presence of dissolved minerals coupled with some special characteristics of groundwater as compared to surface water makes it a preferred choice for many purposes $[2,3]$. The chemical quality of groundwater depends on the characteristics of the soil and rock media through which it passes to the groundwater zone of saturation [4-7]. It is also dependent on the length of time the water is stored in the ground (residence time) [8]. Various researchers carried out the hydrochemical characteristics of groundwater and quality of groundwater in different basins as well in urban areas [9-13].

Groundwater has become the major source of water supply for domestic, industrial and agricultural sectors of many countries. In recent years, many cities of developing countries as Yaounde are experiencing rapid demographic growth due to rural exodus. Actually, more than $48 \%$ of Cameroon population lives in town [14] and 39\% still remain in monetary poverty [14]. Majority of the people in our country depend on agriculture (that is cultivators and agricultural laborers). More than $7.5 \%$ of the Yaounde population practices the urban and peri-urban agriculture in the swampy area to produce leaf vegetables for commercialization and consumption [15]. In this area, both for drinking as well as irrigation purposes substantial amount of groundwater is being used. Hence, evaluation of groundwater resources for development requires an understanding of the hydrogeologic and hydrochemical properties of the aquifers [5].

This study was conducted to determine physical and chemical quality of spring's water from the Mingoa watershed located in urban area of Yaounde and to evaluate its suitability for domestic and agricultural uses. 


\section{Characteristics of Mingoa Watershed}

The Mingoa watershed (Figure 1) is one of 16 basins that make up city of Yaounde which is located within the Mfoundi catchment. This Mingoa watershed in which the outlet is found at the entrance of the "municipal lake" covers an area of 129 ha between longitude $11^{\circ} 29^{\prime} 50^{\prime \prime}$ and $11^{\circ} 30^{\prime} 34^{\prime \prime}$ East and between latitude $3^{\circ} 51^{\prime} 47^{\prime \prime}$ and $3^{\circ} 52^{\prime} 23^{\prime \prime}$ North. It is drained by the Mingoa's river supplied by the springs "Tap Tap" and "Commando" and its tributary the "Ntougou" and constitutes the principal source of the municipal lake. The rugged landform shows interfluves in form of stairs. The average altitude is 734 metres.

The equatorial climate of Guinean type with 4 seasons governs the region. The average annual pluviometry registered on a period of 77 years (1926-2006) is of $1561 \pm$ $223 \mathrm{~mm}$. The annual temperature varies from $22.3^{\circ} \mathrm{C}$ to $24.6^{\circ} \mathrm{C} \pm 2.3^{\circ} \mathrm{C}$. The relative humidity is about $72 \%$ and remains constantly high all through during the year. The bedrock is formed of migmatitic gneiss [16] on which are found on reddish and yellowish ferralitic soil and hydromorphic soil [17]. These geological formations composed by quartz $(25 \%-30 \%)$, K-feldspar $(15 \%-20 \%)$, plagioclase $\mathrm{An}_{30-38}(20 \%-30 \%)$, garnet $(15 \%-20 \%)$, biotite $(5 \%-10 \%)$ and disthene $(2 \%-5 \%)[16]$, constitute potential water zones more or less solicited.

The total population is valued at about $21,500^{1}$ inhabitants in 2003 [18]. In this study area, a diversified and heterogeneous settlement is developed and characterised by the existence of accommodation and trade zones coupled by the agricultural fields. In this agricultural field which is situated in the lowland area, women and youth without employment develop vegetables crops and horticulture for consumption and commercialization to increase household's income. These vegetables crops are generally developed during the dry season and consist to fresh vegetables, lettuces, tomatoes and carrots. By cons, horticulture concerns the production of flowers solicited by populations and beautification projects in city.

\section{Data and Method}

Seven springs were identified and plotted on map using Global Positioning System (Figure 2). In the hydrological year period, discharge was monthly measure such as collecting discharge in a known volume of the bucket over a specific period of time.

Dry, clean and sterilized plastic bottles were used to get fresh aquifer water for sampling. At first the bottles were rinsed by the spring's waters and then collect the water. The collected samples were carefully sealed with proper labeling which preserved in a refrigerator at a

${ }^{1}$ The actual population which is about 35,000 inhabitants is estimated by using the growth rate of Cameroon $(5 \%)$. temperature of about $4^{\circ} \mathrm{C}$ until laboratory analyses. For all samples, temperature, $\mathrm{pH}$ and electrical conductivity (EC) were determined in the field with standard field equipment (WTW/LF 91 temperature/conductivity meter and WTW/pH 90 meter). Samples were then collected and stored in $50 \mathrm{ml}$ preconditioned high-density polythene bottles. Samples were analyzed in the laboratory of wastewater research unit of university of Yaounde I for the major ions chemistry employing standard method [19]. The absolute error of the measurements is estimated at $0.02 \mathrm{mg} / \mathrm{l}$.

The analytical data obtained were processed for detailed geochemical and statistical analysis.

Diagramme software package was used for graphical, numerical and modeling studies. It features a fully customizable database of physical and chemical parameters and it provides a comprehensive selection of analysis tools, calculations and graphs for interpreting water quality data. Basic parametric statistical parameters such as min, max, median, standard deviation (SD) and average were computed along with correlation analysis and factor analysis was carried out by using XLSTAT version 7.5.2.

The sodium adsorption ratios (SAR) of the samples were determined using Equation (3). These values were then plotted against the corresponding EC values on a semi$\log$ plot in accordance with the US Salinity Laboratory [20] scheme. Wilcox diagrams [21] were also plotted to determine the suitability of the groundwater for irrigation activities in the area. The parameters such as SAR and percent sodium $(\mathrm{Na} \%)$ were calculated to evaluate the suitability of the water quality for agricultural purposes.

\section{Results and Discussion}

\subsection{Physicochemical Parameters of Groundwater}

A summary of the physico chemical analysis of the groundwater samples is presented in Table 1.

The $\mathrm{pH}$ values of the groundwater varied from 5.06 to 5.77 with an average value 5.41, indicating an acid type of water. All the groundwater samples are out of the permissible limit prescribed by WHO. EC values ranges from 111.4 to $401.0 \mu \mathrm{s} / \mathrm{cm}$ with an average value of $232.4 \mu \mathrm{s} / \mathrm{cm}$. The maximum limit of EC in drinking water is prescribed as $833 \mu \mathrm{s} / \mathrm{cm}$ according to WHO standard. All the samples are lower than the permissible limit. When we compare these EC values with the values $(<$ $100 \mu \mathrm{s} / \mathrm{cm}$ ) generally observed in superficial aquifer of crystalline zone [22-24], it appears that spring's water in Mingoa watershed are polluted due to the presence of nutrients such as $\mathrm{NH}_{4}^{+}$with concentrations ranged between 1.50 and $53.25 \mathrm{mg} / \mathrm{l}$.

The mean concentration of cation (in meq/l) is in order $\mathrm{Na}^{+}>\mathrm{K}^{+}>\mathrm{Mg}^{2+}>\mathrm{Ca}^{2+}$ while for the anion (in meq/l) it is $\mathrm{Cl}^{-}>\mathrm{HCO}_{3}^{-}>\mathrm{NO}_{3}^{-}>\mathrm{SO}_{4}^{2-}$. 


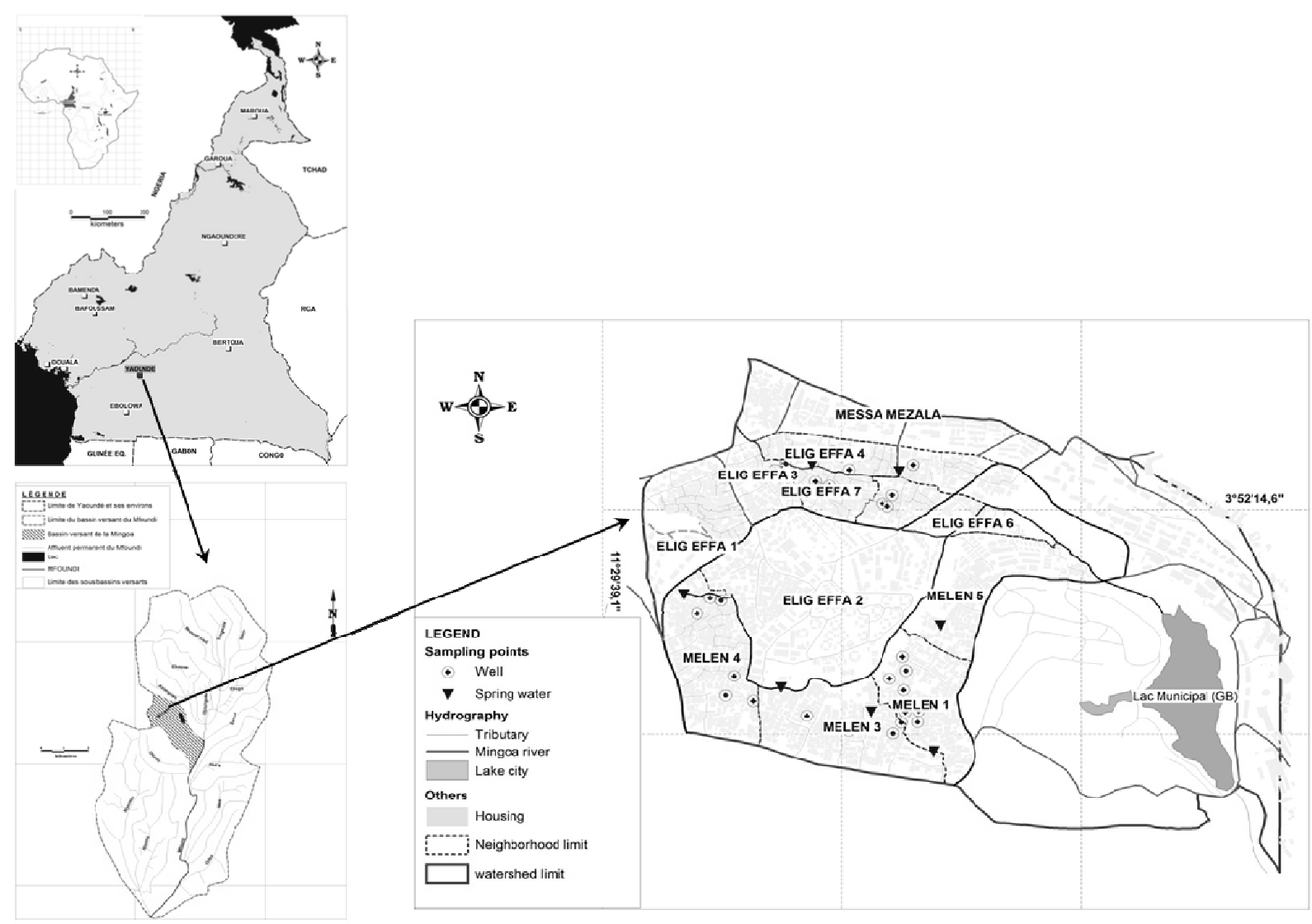

Figure 1. Location of the Mingoa drainage basin (Yaounde-Cameroon).

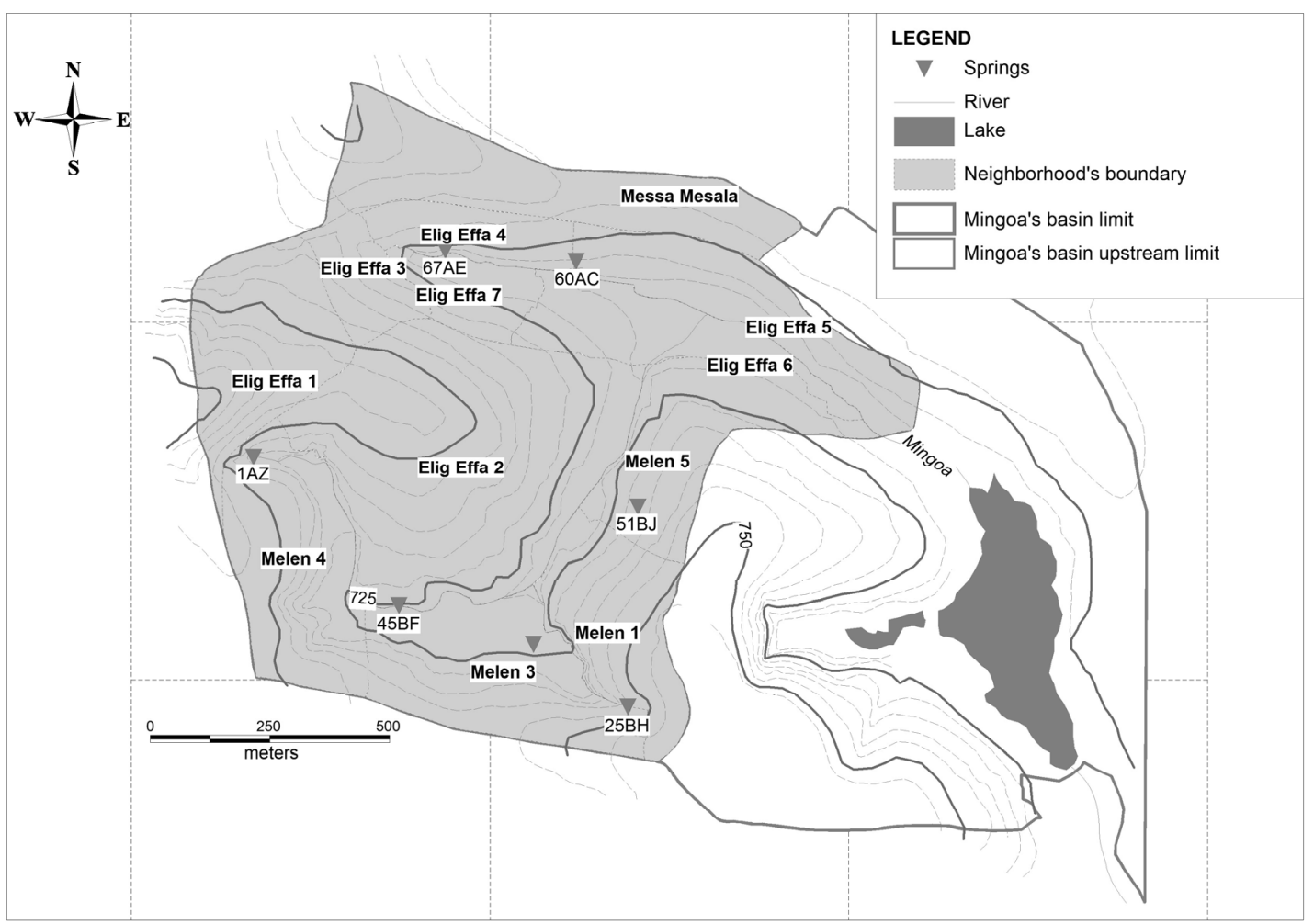

Figure 2. Groundwater sample location map of the Mingoa drainage basin (Yaounde-Cameroon). 
Table 1. Physical and chemical parameters of springs in the Mingoa drainage basin (Yaounde-Cameroon).

\begin{tabular}{|c|c|c|c|c|c|c|c|c|c|c|c|c|}
\hline CODE & $\mathrm{pH}$ & $\begin{array}{c}\mathrm{K}^{+} \\
(\mathrm{mg} / \mathrm{L})\end{array}$ & $\begin{array}{c}\mathrm{Na}^{+} \\
(\mathrm{mg} / \mathrm{L})\end{array}$ & $\begin{array}{c}\mathrm{Mg}^{2+} \\
(\mathrm{mg} / \mathrm{L})\end{array}$ & $\begin{array}{c}\mathrm{Ca}^{2+} \\
(\mathrm{mg} / \mathrm{L})\end{array}$ & $\begin{array}{c}\mathrm{Cl}^{-} \\
(\mathrm{mg} / \mathrm{L})\end{array}$ & $\begin{array}{c}\mathrm{NO}_{3}^{-} \\
(\mathrm{mg} / \mathrm{L})\end{array}$ & $\begin{array}{c}\mathrm{SO}_{4}^{2-} \\
(\mathrm{mg} / \mathrm{L})\end{array}$ & $\begin{array}{l}\mathrm{HCO}_{3}^{-} \\
(\mathrm{mg} / \mathrm{L})\end{array}$ & $\begin{array}{c}\mathrm{NH}_{4}^{+} \\
(\mathrm{mg} / \mathrm{L}) \\
\end{array}$ & $\begin{array}{c}\text { SDT } \\
(\mathrm{mg} / \mathrm{L})\end{array}$ & $\begin{array}{c}\mathrm{EC} \\
(\mu \mathrm{S} / \mathrm{cm})\end{array}$ \\
\hline $25 \mathrm{BH}$ & 5.71 & 6.00 & 9.00 & 0.80 & 0.15 & 111.47 & 5.76 & 1.00 & 64.50 & 14.00 & 52.00 & 119.5 \\
\hline $1 \mathrm{AZ}$ & 5.77 & 3.00 & 7.00 & 0.80 & 0.06 & 58.93 & 19.94 & 1.00 & 34.72 & 53.25 & 222.00 & 401 \\
\hline $51 \mathrm{BJ}$ & 5.66 & 5.00 & 10.00 & 0.61 & 0.09 & 34.08 & 16.39 & 0.00 & 46.23 & 8.00 & 34.00 & 162.7 \\
\hline 28BG & 5.72 & 1.15 & 8.30 & 0.45 & 0.04 & 13.70 & 25.69 & 2.00 & 60.52 & 50.25 & 196.00 & 380 \\
\hline $45 \mathrm{BF}$ & 5.28 & 1.13 & 8.19 & 0.75 & 0.18 & 22.40 & 16.39 & 1.00 & 29.72 & 1.50 & 69.00 & 111.4 \\
\hline $67 \mathrm{AE}$ & 5.29 & 1.19 & 8.63 & 0.46 & 0.07 & 2.80 & 45.19 & 0.00 & 51.81 & 20.00 & 179.00 & 324 \\
\hline $60 \mathrm{AC}$ & 5.74 & 3.00 & 4.00 & 0.70 & 0.99 & 9.29 & 51.39 & 9.00 & 50.20 & 31.75 & 120.00 & 130.4 \\
\hline AVERAGE & 5.60 & 2.92 & 7.87 & 0.65 & 0.23 & 36.10 & 25.82 & 2.00 & 48.24 & 25.54 & 124.57 & 232.71 \\
\hline SD & 0.21 & 1.96 & 1.93 & 0.15 & 0.34 & 38.13 & 16.55 & 3.16 & 12.66 & 20.27 & 75.43 & 129.90 \\
\hline Min & 5.28 & 1.13 & 4.00 & 0.45 & 0.04 & 2.80 & 5.76 & 0.00 & 29.72 & 1.50 & 34.00 & 111.40 \\
\hline Max & 5.77 & 6.00 & 10.00 & 0.80 & 0.99 & 111.47 & 51.39 & 9.00 & 64.50 & 53.25 & 222.00 & 401.00 \\
\hline
\end{tabular}

Sodium concentration varied from 4.00 to $10.00 \mathrm{mg} / \mathrm{l}$, with an average value of $7.87 \mathrm{mg} / \mathrm{l}$. The source of $\mathrm{Na}^{+}$ into the groundwater is due to the weathering of feldspar [25] and meteoric input. The data points of the area on the Gibbs' diagram in Figure 3 suggest chemical weathering of rock-forming minerals and precipitation as origin of the ions. Potassium ion concentration varied from 1.13 to $6.00 \mathrm{mg} / \mathrm{l}$, with an average value of $2.92 \mathrm{mg} / \mathrm{l}$. Potassium is found to be higher due to weathering of K-feldspars and clay minerals from aquifer matrix [26]. $\mathrm{Mg}^{2+}$ ion concentration varied from 0.45 to $0.80 \mathrm{mg} / \mathrm{l}$, with an average value of $0.65 \mathrm{mg} / \mathrm{l} . \mathrm{Ca}^{2+}$ ion concentration varied from 0.04 to $0.99 \mathrm{mg} / \mathrm{l}$, with an average of $0.23 \mathrm{mg} / \mathrm{l}$. It is observed that all groundwater samples from the study area are within permissible limit according to WHO standard except ammonium ion. $\mathrm{Ca}^{2+}$ and $\mathrm{Mg}^{2+}$ are higher, due to the weathering of ferromagnesian minerals [22].

Chloride ion concentration varied from 2.80 to 111.47 $\mathrm{mg} / \mathrm{l}$, whereas bicarbonate ranged between 27.72 and $64.50 \mathrm{mg} / \mathrm{l}$ with an average value of $48.24 \mathrm{mg} / \mathrm{l}$.

Bicarbonate is higher due to the presence of $\mathrm{CO}_{2}$ in water from soil which facilitates the hydrolysis as following reaction:

$$
\mathrm{CO}_{2}+\mathrm{H}_{2} \mathrm{O} \leftrightarrow \mathrm{H}_{2} \mathrm{CO}_{3} \leftrightarrow \mathrm{HCO}_{3}^{-}+\mathrm{H}^{+}
$$

This reaction is also favored by the production of $\mathrm{CO}_{2}$ by plants which allows the formation of $\mathrm{HCO}_{3}^{-}$by cons, the presence of chloride in our study area is explained by barriers to the flow of water in the weathered clay [27] and also due to domestic wastages and/or leaching from upper soil layers in dry climates [28]. It was found that amount of sulfate ranged from 0.00 to $9.00 \mathrm{mg} / \mathrm{l}$ and all samples were below the permissible limit according to WHO standard.

Higher $\mathrm{SO}_{4}^{2-}$ is noted in $60 \mathrm{AC}$ spring due to anthropogenic activities around this spring's area such as car

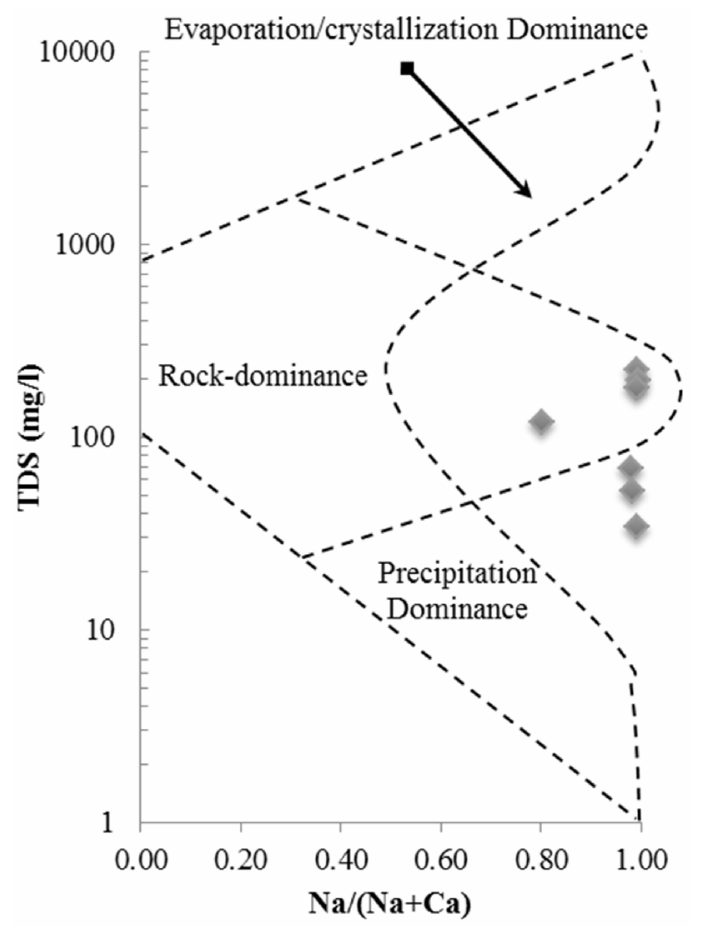

Figure 3. Mechanism governing groundwater chemistry.

wash, where wastewater rich in sulphur flow and enter into the groundwater. It also prove that the biological actions may also be involved mechanically (plant roots) especially by generating chemicals (humic compounds, ammonias, $\mathrm{CO}_{2}, \mathrm{HCO}_{3}^{-}, \mathrm{PO}_{4}^{3-}$ and $\mathrm{SO}_{4}^{2-}$ ). This would also explain especially the presence of sulfate in groundwater [29].

Nitrate values varied from 5.76 to $51.39 \mathrm{mg} / \mathrm{L}$. Nearly $28 \%$ of the groundwater exceeds the standard desirable limit of $50 \mathrm{mg} / \mathrm{l}$, according to WHO standards. All of these sampling points are very close to domestic area which is characterized by the abundant presence of pit 
toilets. These pit toilets are in direct contact with superficial aquifer [30]. It is observed that in the swampy lowlands where vegetable crops are located, nitrate concentrations in the groundwater sample increase and exceed the standard desirable limit. $\mathrm{NO}_{3}^{-}$ion concentration in excess in drinking water creates several problems [31] like cyanosis, tumors goiter, oral cancer, cancer of colon, rectum or other gastrointestinal cancer, lymphoma, and dyspnea, and high nitrate ion concentrate in groundwater poses a small but well-recognized risk to bottle fed babies known as methemoglobinemia.

\subsection{Statistical Analysis}

The correlation matrix allows us to distinguish several relevant hydrochemical relationships. The contents of $\mathrm{NO}_{3}^{-}, \mathrm{Ca}^{2+}$ and $\mathrm{SO}_{4}^{2-}$ are positively correlated to runoff with correlation coefficients of $0.890,0.868$, and 0.814 , respectively. These values indicate that these three ions are more mobilized when the flow increases as show in Table 2.

Indeed, a strong positive correlation was found between $\mathrm{K}^{+}$and $\mathrm{Cl}^{-}, \mathrm{Ca}^{2+}$ and $\mathrm{SO}_{4}^{2-}$ and it can also be deduced that for most of the groundwater samples these parameters originate from a common source. Sodium and calcium are negatively interrelated among themselves $(\mathrm{r}=$ $-0.861)$. This interrelationship indicates the permanent cation's exchange process between water and soil minerals (clays).

Figure 4 shows the behavior of the variables (chemical parameters). The main contributions to F1 probably include both natural and anthropogenic elements. The F1 which explains $\approx 45.0 \%$ of the total variance had high positive scores on $\mathrm{Ca}^{2+}, \mathrm{SO}_{4}^{2-}, \mathrm{NO}_{3}^{-}$, and Flow. Except $\mathrm{Ca}^{2+}$ which originates from lithological processes taking place here which include weathering of rocks minerals such as anorthite, we can notice that run-off from agriculture activities may be responsible for the high concentrations of nitrates in water in the area [32] because of lack of correlation between nitrate and nitrite or ammonia (Table 2). This is also evidence of interaction of the wetland with the groundwater. By cons, the F2 which explains $\approx 30.2 \%$ of the total variance had high positive scores on $\mathrm{K}^{+}, \mathrm{Mg}^{2+}$, and $\mathrm{Cl}^{-}$which represent the group of natural influences. These ions have significant lithological origin and thus could likely be sourced from the weathering of some minerals. It is observed the opposition of $\mathrm{Ca}^{2+}$ and $\mathrm{Na}^{+}$which confirm the constant interaction between clays minerals and groundwater.

\subsection{Hydrochemical Facies}

Major cations and anions such as $\mathrm{Ca}^{2+}, \mathrm{Mg}^{2+}, \mathrm{Na}^{+}, \mathrm{K}^{+}$, $\mathrm{CO}_{3}^{-}, \mathrm{HCO}_{3}^{-}, \mathrm{SO}_{4}^{2-}$, and $\mathrm{Cl}^{-}$in $\mathrm{mg} / \mathrm{L}$ were plotted in Piper diagram [33] to evaluate the hydrochemistry of groundwater of Mingoa watershed and it is adjoining area with the help of Diagramme-software (Figure 5). The plot shows that groundwater samples fall in the field of $\mathrm{Na}^{+}-\mathrm{K}^{+}-\mathrm{Cl}^{-}-\mathrm{SO}_{4}^{2-}$ and $\mathrm{Na}^{+}-\mathrm{K}^{+}-\mathrm{HCO}_{3}^{-}-$ $\mathrm{CO}_{3}^{-}$type water.

\subsection{Water for Irrigation Purpose}

The quality of water used for irrigation is vital for crop yield, maintenance of soil productivity and protection of the environment [34]. At the same time, the quality of irrigation water is very much influenced by the land constituents of the water source.

For the purpose of this work, $\mathrm{Na} \%$ and $\mathrm{SAR}$, were used to determine the suitability of the groundwater for irrigation purposes (Table 3).

Table 2. Pearson correlation of major ions, $\mathrm{pH}, \mathrm{NO}_{2}^{-}, \mathrm{NH}_{4}^{+}$and flow.

\begin{tabular}{|c|c|c|c|c|c|c|c|c|c|c|c|c|}
\hline & Flow & $\mathrm{pH}$ & $\mathrm{K}^{+}$ & $\mathrm{Na}^{+}$ & $\mathrm{Mg}^{2+}$ & $\mathrm{Ca}^{2+}$ & $\mathrm{Cl}^{-}$ & $\mathrm{NO}_{3}^{-}$ & $\mathrm{SO}_{4}^{2-}$ & $\mathrm{HCO}_{3}^{-}$ & $\mathrm{NO}_{2}^{-}$ & $\mathrm{NH}_{4}^{+}$ \\
\hline Flow & 1 & & & & & & & & & & & \\
\hline $\mathrm{pH}$ & -0.146 & 1 & & & & & & & & & & \\
\hline $\mathrm{K}^{+}$ & -0.305 & 0.547 & 1 & & & & & & & & & \\
\hline $\mathrm{Na}^{+}$ & -0.780 & -0.291 & 0.214 & 1 & & & & & & & & \\
\hline $\mathrm{Mg}^{2+}$ & -0.126 & 0.256 & 0.508 & -0.252 & 1 & & & & & & & \\
\hline $\mathrm{Ca}^{2+}$ & 0.868 & 0.234 & 0.053 & -0.861 & 0.227 & 1 & & & & & & \\
\hline $\mathrm{Cl}^{-}$ & -0.583 & 0.413 & 0.777 & 0.284 & 0.667 & -0.253 & 1 & & & & & \\
\hline $\mathrm{NO}_{3}^{-}$ & 0.890 & -0.150 & -0.493 & -0.651 & -0.459 & 0.613 & -0.746 & 1 & & & & \\
\hline $\mathrm{SO}_{4}^{2-}$ & 0.814 & 0.373 & -0.041 & -0.912 & 0.144 & 0.962 & -0.279 & 0.619 & 1 & & & \\
\hline $\mathrm{HCO}_{3}^{-}$ & -0.012 & 0.364 & 0.337 & 0.139 & -0.386 & 0.031 & 0.251 & 0.051 & 0.110 & 1 & & \\
\hline $\mathrm{NO}_{2}^{-}$ & -0.159 & 0.213 & -0.431 & 0.082 & -0.659 & -0.225 & -0.297 & 0.078 & 0.011 & 0.478 & 1 & \\
\hline $\mathrm{NH}_{4}^{+}$ & -0.010 & 0.598 & -0.253 & -0.425 & -0.156 & 0.019 & -0.088 & 0.253 & 0.253 & 0.139 & 0.543 & 1 \\
\hline
\end{tabular}


Table 3. Classification of groundwater quality based on EC, Na\%, SAR, for suitability of irrigation the Mingoa drainage basin (Yaounde-Cameroon).

\begin{tabular}{|c|c|c|c|c|}
\hline Parameters & Range & Class & $\mathrm{N}^{\circ}$ of sample & Percentage of the samples \\
\hline & $<250$ & Excellent & $25 \mathrm{BH} ; 51 \mathrm{BJ} ; 45 \mathrm{BF} ; 60 \mathrm{AC}$ & $57.1 \%$ \\
\hline & $250-750$ & Good & $1 \mathrm{AZ} ; 28 \mathrm{BG} ; 67 \mathrm{AE}$ & $42.9 \%$ \\
\hline \multirow[t]{4}{*}{$\begin{array}{l}\text { EC (Electrical } \\
\text { conductivity) }\end{array}$} & $750-2000$ & Permissible & - & - \\
\hline & $2000-3000$ & Doubtful & - & - \\
\hline & $>3000$ & Unsuitable & - & - \\
\hline & $<200$ & Maximum allowable limit & 25BH: 51BJ; 45BF; 60AC; $1 \mathrm{AZ} ; 28 \mathrm{BG} ; 67 \mathrm{AE}$ & $100.0 \%$ \\
\hline \multicolumn{5}{|l|}{$\mathrm{Na} \%$} \\
\hline & $<20$ & Excellent & 25BH: 51BJ; 45BF; 60AC; $1 \mathrm{AZ} ; 28 \mathrm{BG} ; 67 \mathrm{AE}$ & $100.0 \%$ \\
\hline & $20-40$ & Good & - & - \\
\hline \multirow{3}{*}{$\begin{array}{l}\text { SAR (Sodium } \\
\text { Adsorption } \\
\text { Ratio) }\end{array}$} & $40-60$ & Permissible & - & - \\
\hline & $60-80$ & Doubtful & - & - \\
\hline & $>80$ & Unsuitable & - & - \\
\hline
\end{tabular}

Variables (axes F1 et F2 : $78.12 \%)$

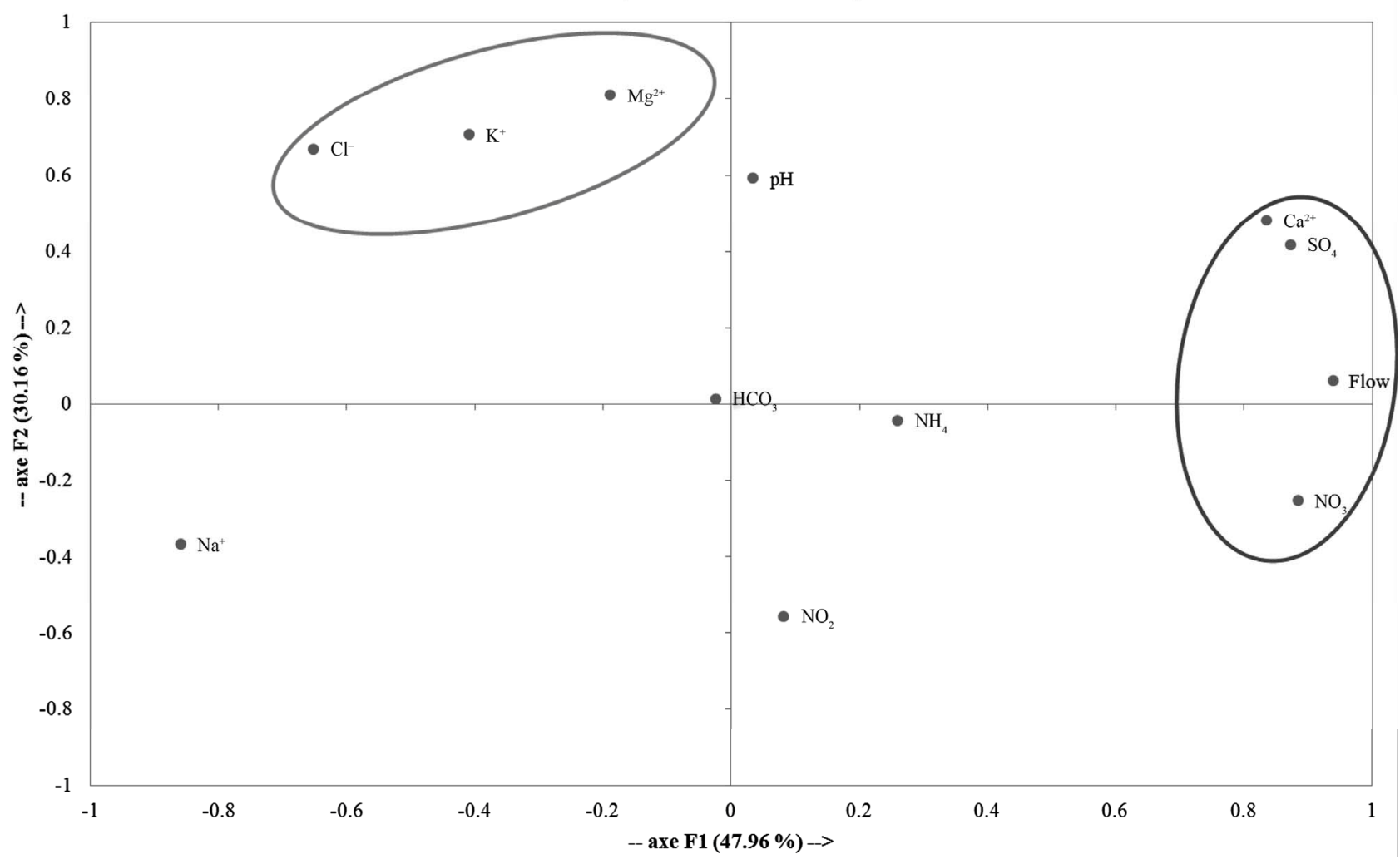

Figure 4. Representation of the F scores on the first two factors for the Mingoa springs waters: Loading plot of variables. 


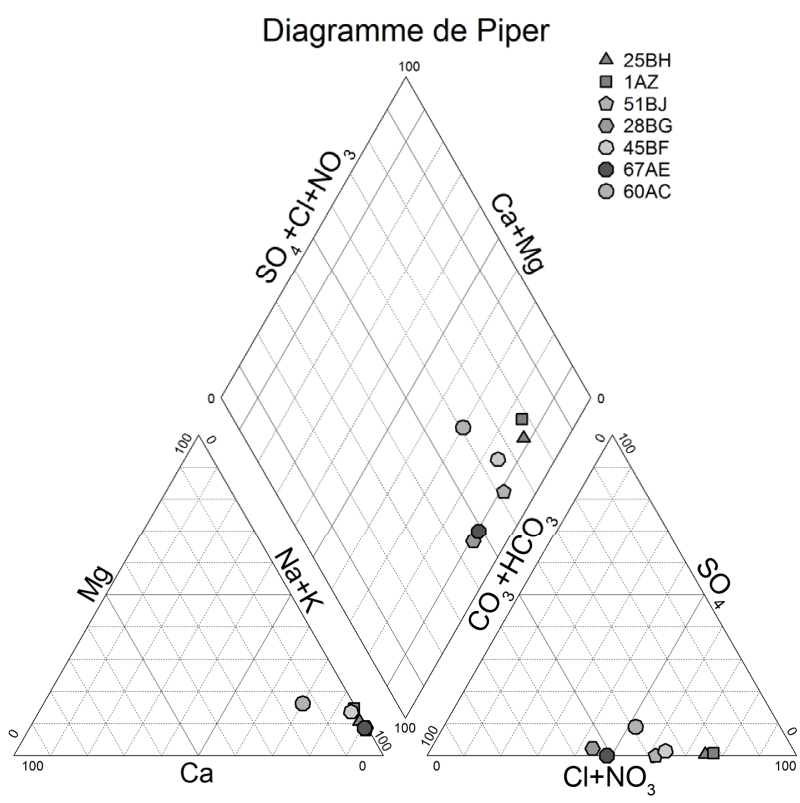

Figure 5. Piper diagram of groundwater in Mingoa watershed (Yaounde-Cameroon).

\subsubsection{Sodium Percentage}

Sodium is an important ion used for the classification of irrigation water due to its reaction with soil, reduces its permeability. Sodium is usually expressed in terms of percent sodium or soluble-sodium percentage $(\mathrm{Na} \%)$. Percentage of $\mathrm{Na}^{+}$is widely used for assessing the suitability of water for irrigation purposes [35]. The $\mathrm{Na} \%$ is computed with respect to relative proportion of cations present in water as

$$
\mathrm{Na} \%=\left(\frac{\mathrm{Na}^{+}+\mathrm{K}^{+}}{\mathrm{Ca}^{2+}+\mathrm{Mg}^{2+}+\mathrm{Na}^{+}+\mathrm{K}^{+}}\right) \times 100 \%
$$

Here all the concentrations are expressed in meq/l.

The values of sodium percent are varying from $70.1 \%$ to $91.1 \%$ and are less than 200 (maximum allowable limit). The classification of samples is shown in Table 3.

Higher $\mathrm{Na} \%$ is observed indicating the dominance of ion exchange and weathering from litho-units of the study area. When the concentration of sodium ion is high in irrigation water, $\mathrm{Na}^{+}$tends to be absorbed by clay particles, displacing magnesium and calcium ions. This exchange process of sodium in water for $\mathrm{Ca}^{2+}$ and $\mathrm{Mg}^{2+}$ in soil reduces the permeability and eventually results in soil with poor internal drainage.

\subsubsection{Sodium Adsorption Ratio}

Total salt concentration and probable sodium hazard of the irrigation water are the two major constituents for determining SAR. Salinity hazard is based on EC measurements.

If water used for irrigation is high in $\mathrm{Na}^{+}$and low in $\mathrm{Ca}^{2+}$ the ion-exchange complex may become saturated with $\mathrm{Na}^{+}$which destroys the soil structure, due to the dispersion of clay particles [36] and reduces the plant growth.

Excess salinity reduces the osmotic activity of plants [10].

The SAR is computed, using the formula [37]

$$
\mathrm{SAR}=\frac{\mathrm{Na}^{+}}{\sqrt{\frac{\mathrm{Ca}^{2+}+\mathrm{Mg}^{2+}}{2}}}
$$

Concentrations of ions are expressed in meq/l. There is a close relationship between SAR values in irrigation water and the extent to which $\mathrm{Na}^{+}$is absorbed [38].

The computed SAR values ranges from 0.8 to 2.6 meq/1 (Table 3). All samples are suitable (excellent) for irrigation. The analytical data plot on the US salinity diagram [39] illustrates that $42.9 \%$ of the groundwater samples fall in the field of C1S1, indicating low salinity and low sodium water, which can be used for irrigation on almost all type of soil with little danger of exchangeable sodium (Figure 6). $57.1 \%$ of the sample falls in C2S1 zone indicating medium salinity and low sodium, which can be used for irrigation in almost all types of soil with little danger of exchangeable sodium [40].

\section{Conclusions}

Groundwater is immensely important for water supply in both the urban and rural areas of developing nations. The groundwater in the study area is acid in nature.

The groundwater quality in Mingoa basin has been evaluated for their chemical composition and suitability for domestic and agricultural uses. The order of abun-

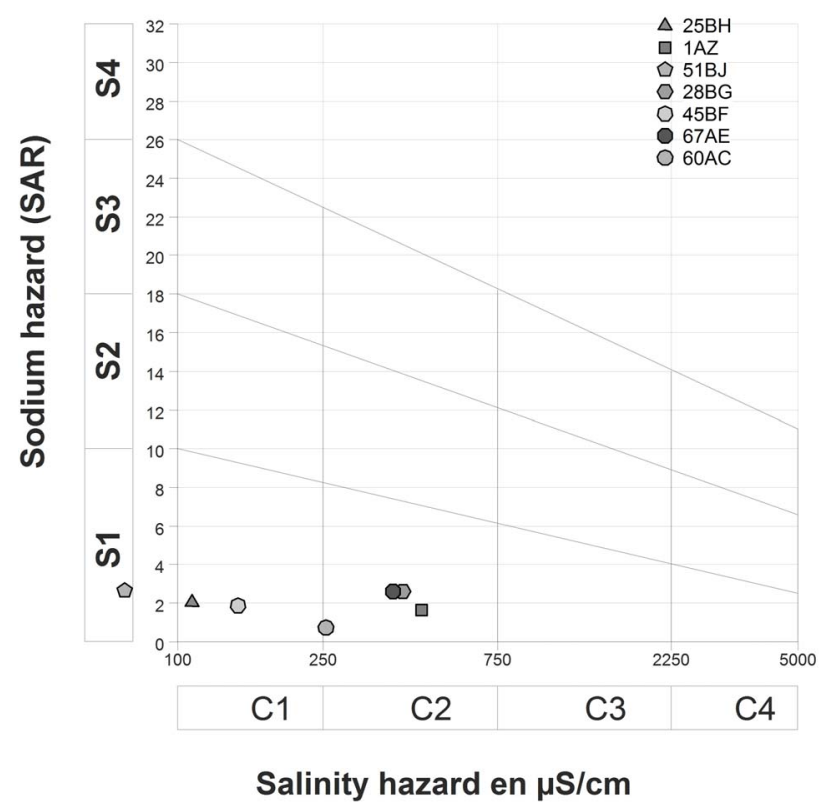

Figure 6. Suitability of groundwater for irrigation USSL (1954) diagram. 
dance of chemical concentration is $\mathrm{Na}^{+}>\mathrm{K}^{+}>\mathrm{Mg}^{2+}>$ $\mathrm{Ca}^{2+}=\mathrm{Cl}^{-}>\mathrm{HCO}_{3}^{-}>\mathrm{NO}_{3}^{-}>\mathrm{SO}_{4}^{2-}$ and $\mathrm{Na}^{+}>\mathrm{Mg}^{2+}$ $>\mathrm{K}^{+}>\mathrm{Ca}^{2+}=\mathrm{HCO}_{3}^{-}>\mathrm{Cl}^{-}>\mathrm{NO}_{3}^{-}>\mathrm{SO}_{4}^{2-}$ for the groundwater sample. The Piper diagram indicates the action of $\mathrm{CO}_{2}$ which chemically reacts upon the minerals present in soil and granitic rock releases $\mathrm{HCO}_{3}^{-}$and reverse ion exchange process controls the water chemistry in the study area. Higher EC values are confined along up stream, indicating the influence of local lithology and anthropogenic activities. Higher $\mathrm{NO}_{3}^{-}$was observed in areas where field vegetables crops are dominant. Higher $\mathrm{Na} \%$ is observed, indicating the dominance of ion exchange and weathering from minerals of the study area. SAR is found to be lower indicating leaching and dissolution of salts during precipitation infiltrates into the aquifer matrix are done in crystalline zone context. The USSL plot shows that $42.9 \%$ of samples fall in $\mathrm{C} 1 \mathrm{~S} 1$ zone, indicating low salinity and low sodium water, which can be used for irrigation in almost all types of soil with little danger of exchangeable sodium. Overall hydrogeochemical analytical study reveals all of the samples have suitable for irrigation purposes because, the concentrations of each parameter are very low and within the permissible limit. The most conspicuous change in chemistry of groundwater is relative enrichment of nitrate beyond permissible limits $(>50 \mathrm{mg} / \mathrm{l})$ of drinking water standards for the samples which are located in swampy area.

\section{Acknowledgements}

This work was supported by International Development of Research Center (IDRC). We pay tribute to Dr. DJEUDA TCHAPNGA Henry Bosko, the project manager and supervisor of the thesis of author who died tragically by accident.

\section{REFERENCES}

[1] M. Vasanthavigar, K. Srinivasamoorthy, K. Vijayaragavan, R. Rajiv Ganthi, S. Chidambaram, V. S. Sarama, P. Anandhan, R. Manivannan and S. Vasudevan, "Application of Water Quality Index for Groundwater Quality Assessment: Thirumanimuttar Sub-Basin, Tamilnadu, India," Environmental Monitoring and Assessment, Vol. 171, No. 1-4, 2010, pp. 595-609.

[2] P. N. Rajankar, S. R. Gulhane, D. H. Tambekar, D. S. Ramteke and S. R. Wate, "Water Quality Assessment of Groundwater Resources in Nagpur Region (India) Based on WQI," E-Journal of Chemistry, Vol. 6, No. 3, 2009, pp. 905-908. doi:10.1155/2009/971242

[3] P. K. Goel, "Water Pollution-Causes, Effects and Control," New Age Int. (P) Ltd., New Delhi, 2000.

[4] B. A. Raji and S. A. Alagbe, "Hydrochemical Facies in Parts of the Nigerian Basement Complex," Environmental Geology, Vol. 29, No. 1-2, 1997, pp. 46-49. doi: $10.1007 / \mathrm{s} 002540050102$

[5] S. Y. Acheampong and J. W. Hess, "Hydeogeological and Hydrochemical Framework of the Shallow Groundwater System in the Southern Voltaian Sedimentary Basin, Ghana," Hydrogeology Journal, Vol. 6, No. 4, 1998, pp. 527-537.

[6] A. I. Olayinka, A. F. Abimbola, R. A. Isibor and A. B. Rafiu, "A Geoelectric Hydrochemical Investigation of Shallow Groundwater Occurrence in Ibadan, SouthWestern Nigeria," Environmental Geology, Vol. 37, No. 1-2, 1999, pp. 31-37. doi:10.1007/s002540050357

[7] S. Foster, J. Chilton, M. Moench, F. Cardy and M. Schiffer, "Groundwater in Rural Development," WTP 463, 2000.

[8] A. M. MacDonald, J. Davies and B. E. O. Dochartaigh, "Simple Methods for Assessing Groundwater Resources in Low Permeability Areas in Africa," BGS Commissioned Report, 2002, $71 \mathrm{p}$.

[9] Y. S. Rao, T. V. K. Reddy and P. T. Nayudu, "Groundwater Quality in the Niva River Basin, Chittoor District, Andhra Pradesh, India," Environmental Geology, Vol. 31, No. 1, 1997, pp. 56-63. doi:10.1007/s002540050193

[10] T. Subramani, L. Elango and S. R. Damodarasamy, "Groundwater Quality and Its Suitability for Drinking and Agricultural Use in Chithar River Basin, Tamil Nadu, India," Environmental Geology, Vol. 47, No. 8, 2005, pp. 1099-1110. doi:10.1007/s00254-005-1243-0

[11] R. Umar, M. M. A. Khan and A. Absar, "Groundwater Hydrochemistry of a Sugarcane Cultivation Belt in Parts of Muzaffarnagar District, Uttar Pradesh, India," Environmental Geology, Vol. 49, No. 7, 2006, pp. 999-1008. doi:10.1007/s00254-005-0138-4

[12] K. Pandian, and K. Sankar, "Hydrogeochemistry and Groundwater Quality in the Vaippar River Basin, Tamil Nadu," Journal of the Geological Society of India, Vol. 69, 2007, pp. 970-982.

[13] N. J. Raju, "Hydrogeochemical Parameters for Assessment of Groundwater Quality in the Upper Gunjanaeru River Basin, Cuddapah District, Andhra Pradesh," South India Environmental Geology, Vol. 52, 2007, pp. $1067-$ 1074. doi:10.1007/s00254-006-0546-0

[14] INS (Institut National de la Statistique), "Annuaire Statistique du Cameroun," 2010, 414 p. http://www.statistics-cameroon.org/news.php

[15] UNDP (United Nations for Development Program), "Urban Agriculture: Food, Jobs and Sustainable Cities," UNDP, New York, 1996.

[16] J. P. Nzenti, P. Barbey, J. Macaudière and D. Soba, "Origin et Evolution of the Late Precambrian High Grade Yaounde Yaoundé Gneiss (Cameroun)," Precambrian Research, Vol. 38, No. 2, 1988, pp. 91-109. doi:10.1016/0301-9268(88)90086-1

[17] Onguene Mala, "Différenciations Pédologiques dans la Région de Yaoundé (Cameroun): Transformation d'un sol Rouge Ferrallitique en sol à Horizon Jaune en Relation avec l'Evolution du Modelé," Thèse Doct. Univ. Paris VI, 1993, $254 \mathrm{p}$.

[18] LESEAU (Laboratoire Environnement et Sciences de 
l'Eau), "Maîtrise de l'Assainissement dans un Ecosystème Urbain à Yaoundé au Cameroun et Impacts sur la Santé des Enfants Agés de Moins de Cinq Ans," Rapport Final de Recherche Phase I, 2005, 207 p.

[19] APHA (American Public Health Association), "Standard Methods for Examination of Water and Waste Water," American Public Health Association, American Water Works Association and Water Pollution Control Federation, Washington DC, USA, 1995.

[20] USSL (United States Salinity Labortory), "Diagnosis and Improvements of Saline and Alkali Soils," US Department of Agricultural Soils, US Department of Agricultural Hand Book 60, Washington, 1954.

[21] L. V. Wilcox, "Classification and Use of Irrigation Waters," USDA, Circular 969, Washington DC, 1955.

[22] A. Nono, J. D. H. Likeng, H. Wabo, J. G. Tabue Youmbi and S. Biaya, "Influence de la Nature Lithologique et des Structures Géologiques sur la Qualité et la Dynamique des eaux Souterraines dans les Hauts Plateaux de l'Ouest-Cameroun," Journal of Biological Chemistry Science, Vol. 3, No. 2, 2009, pp. 218-239.

[23] C. Grimaldi, E. Fritsch and R. Boulet, "Composition Chimique des eaux de Nappe et Evolution d'un Matériau Ferrallitique en Présence du Système MuscoviteKaolinite-Quartz," Compte rendus de L'Académie des Sciences de Paris, Série II, Vol. 319, 1994, pp. 13831389.

[24] J. P. Faillat and C. Drogue, "Différenciation Hydrochimique des Nappes Superposées d'Altérites et de Fissure en Socle Granitique," Journal of Science Hydrologiques, Vol. 38, No. 3, 1993, pp. 215-229.

[25] J. D. Hem, "Study and Interpretation of the Chemical Characteristics of Natural Water," 3rd Edition, Scientific, Jodhpur, 1985, p. 2254.

[26] E. Lakshmanan, K. Kannan and M. SenthilKumar, "Major Ion Chemistry and Identification of Hydrogeochemical Process of Groundwater in Part of Kancheepuram District, Tamilnadu, India," Journal Environmental Geosciences, Vol. 10, No. 4, 2003, pp. 157-166. doi:10.1306/eg100403011

[27] A. Savadogo Nindaoua, "Géologie et Hydrogéologie du Socle Cristallin de Haute Volta. Etude Régionale du Bassin versant de la Sissili," Doct. Etat Faculté des Sciences. Grenoble, Université des Sciences Techniques et Médicales de Grenoble I, 1984, 349 p.

[28] K. Srinivasamoorthy, S. Chidambaram and M. Vasanthavigar, "Geochemistry of Fluorides in Groundwater: Salem District, Tamilnadu, India," Journal of Environmental Hydrology, Vol. 1, 2008, pp. 16-25.

[29] S. Diouf, "Hydrogéologie en Zone de Socle Cristallin et
Cristallophylien du Sénégal oriental: Application de la Méthode Electrique $1 \mathrm{D}$ et $2 \mathrm{D}$ à la Localisation et à la Caractérisation des Aquifères du Batholite de Saraya et ses Environs," Thèse Doct. $3^{\text {ème }}$ cycle, Univ. Cheikh Anta Diop, Dakar, 1999, 160 p.

[30] J. G. Tabué Youmbi, D. Ntamack, R. Feumba, E. Ngnikam, J. Wethe and E. Tanawa, "Vulnérabilité des eaux Souterraines et Périmètres de Protection dans un Bassin versant de la Mingoa (Yaoundé, Cameroun)," Revue de l'Université de Moncton, Vol. 40, No. 2, 2009, pp. 71-96.

[31] P. C. Mishra, P. C. Behera and R. K. Patel, "Contamination of Water Due to Major Industries and Open Refuse Dumping in the Steel City of Orissa-A Case Study," Journal of Environmental Science \& Engineering, Vol. 47, No. 2, 2005, pp. 141-154.

[32] T. Venugopal, L. Giridharan and M. Jayaprakash, “Application of Chemometric Analysis for Identifying Pollution Sources: A Case Study on the River Adyar, India," Marine and Freshwater Research, Vol. 60, No. 12, 2009, pp. 1254-1264. doi:10.1071/MF08178

[33] A. M. Piper, "A Graphic Procedure in the Geochemical Interpretation of Water Analysis," USGS Ground Water Note, No. 12, 1953, 63 p.

[34] V. Singh and U. C. Singh, "Assessment of Groundwater Quality of Parts of Gwalior (India) for Agricultural Purposes," Indian Journal of Science and Technology, Vol. 1, No. 4, 2008, pp. 1-5.

[35] L. V. Wilcox, "Classification and Use of Irrigation Waters," USDA, Circular 969, Washington DC, 1955.

[36] D. K. Todd, "Ground Water Hydrology," Wiley, New York, 1980.

[37] J. D. Hem, "Study and Interpretation of the Chemical Characteristics of Natural Waters," Book 2254, 3rd Edition, Scientific Publishers, Jodhpur, 1991.

[38] N. Subba Rao, "Seasonal Variation of Groundwater Quality in a Part of Guntur district, Andhra Pradesh, India," Environmental Geology, Vol. 49, No. 3, 2006, pp. 413429. doi:10.1007/s00254-005-0089-9

[39] L. V. Wilcox, "The Quality of Water for Irrigation Use," US Department of Agriculture, Technical Bulletin, Vol. 962, No. 40, U.S. Department of Agriculture, Washington DC, 1948.

[40] M. Kumar, K. Kumari, A. L. Ramanathan and R Saxena, "A Comparative Evaluation of Groundwater Suitability for Irrigation and Drinking Purposes in Two Intensively Cultivated Districts of Punjab, India," Environmental Geology, Vol. 53, No. 3, 2007, pp. 553-574. doi:10.1007/s00254-007-0672-3 